\title{
Learning achievement reviewed from self regulated learning, future orientation, and parental support
}

\author{
Yuzarion Yuzarion ${ }^{1 *}$, Aulia Kartika Agustiana ${ }^{2}$, Alfaiz Alfaiz ${ }^{3}$, Hengki Yandri ${ }^{4}$, Musdizal \\ Musdizal $^{5}$, Rahmadianti Aulia ${ }^{6}$ \\ ${ }^{12}$ Universitas Ahmad Dahlan, Indonesia \\ ${ }^{3}$ STKIP PGRI Sumatera Barat, Indonesia \\ ${ }^{45}$ IAIN Kerinci, Indonesia \\ ${ }^{6}$ Universitas Islam Negeri Imam Bonjol Padang, Indonesia \\ *)Corresponding author, Ðe-mail: yuzarion@psy.uad.ac.id
}

\begin{abstract}
This study aimed to answer the main problem whether learning achievement could be viewed from self-regulated learning, future orientation and parental support to obtain empirical support. This research used quantitative methods, the sample of 103 people. The data was collected with instruments, scale (1) self-regulated learning, (2) future orientation and (3) parental support. Learning achievement used report card grades. The results showed that learning achievement could be viewed from self-regulated learning, future orientation and parental support. It got very significant empirical support., score $\mathrm{F}$ reg $=43,155$ dan $p=0,000(p<0,01)$. Self-regulated learning, future orientation, and parental support provided an effective contribution of $55.4 \%$ to learning achievement. The biggest SE was from parental support $37.4 \%$, followed by self-regulated learning $12.7 \%$, and future orientation $6.6 \%$. Based on the findings, the researcher suggests: (1) parents need to maximize learning support for children, strengthen emotional support, instrumental, and informative support. (2) teachers need to introduce self-regulated learning to students. (3) teachers and parents to explore the future orientation of children or students well, so that they grow stronger for a more planned future. And (4) researchers recommend the following research in elementary, junior high, senior high school and PT.
\end{abstract}

Keywords: Learning achievement, self-regulated learning, future orientation, and parental support.

How to Cite: Yuzarion, Y., Agustiana, A., Alfaiz, A., Yandri, H., Musdizal, M., \& Aulia, R. (2020). Learning achievement reviewed from self regulated learning, future orientation, and parental support. COUNS-EDU: The International Journal of Counseling and Education, 5(2), 71-80. DOI: http://dx.doi.org/10.23916/0020200526820

This is an open access article distributed under the Creative Commons Attribution License, which permits unrestricted use, distribution, and reproduction in any medium, provided the original work is properly cited. (C2020 by author.

\section{Introduction}

The problem of learning achievement until now has never faded to be studied, it is not infinite the number of studies that make learning achievement variables. There are still many reports that explain the problem of low students' achievement including the Trends in International Mathematics and Science Study (TIMSS) report in 2017, it still shows the low achievement in mathematics of Indonesian students, data obtained from 50 Indonesian student countries ranks fifth lowest with a score an average of 379 (nces.ed.gov/timss, accessed November 2019).

The Measurement Program for the International Student Assessment (PISA) of Indonesia in 2018, carried out by the Organization for Economic Cooperation and Development (OECD), of 12.098 students 
spread across 399 schools throughout Indonesia, Indonesian-sponsored mathematics and science scores below the average flat. Indonesian students are only able to obtain an average score of 379 in mathematics and an average score of 396. This PISA score is below the mathematics and science scores obtained by Singapura students, an average of 591 and 569 (kompas.com, accessed November 2019) .

The results of the umbrella research survey of 6 September 2019, also obtained information from the deputy head of the curriculum of student learning achievement. It is still the most in the medium category as much as 68.77 percent of 143 students who took the final exam. From the student's point of view, it is really very worrying, the findings of previous research also identify behaviors that illustrate low learning achievement. Cheating behavior is also still rife among students, even though the national examination competition was not as heavy as five years ago. Thorpe's research (Yuzarion, 2015a) explains that cheating behavior occurs due to low student achievement, besides the ability of the participants is indeed low, while they have a desire to get higher learning achievement.

Based on the problems above, when analyzed using social cognitive theory from Bandura. The causes of low learning achievement can be explained through internal and external factors of students. Internal factors of students can be caused by weak self-regulated learning and future orientation that has not been formed properly, this corresponds to the process of forethought aspects that are potential in learners that must be formed (Alfaiz, et, al, 2015, 2018, 2019). External factors can also be caused by students not functioning properly with parental support.

Look deeper into social cognitive theories, especially those relating to one-way relationships. Previous research findings can explain the factors that influence learning achievement. The results of the Cekolin experiment (2010), the academic achievements of students who take self-regulated learning training are higher than those who do not attend training. Yuzarion's research (2015a) also proves that there is a relationship between self-regulated learning and the learning achievements of Malang City High School students. then it can be understood that learning achievement can be viewed from self-regulated learning.

Self regulated learning is the ability of individuals to organize themselves in learning. Self regulated learning is also understood as a learning skill, a skill to set learning goals, self-control in learning, seeking learning assistance, learning motivation, learning strategies, and self-evaluation in learning Yuzarion (2015b). This further strengthens learning achievement can be viewed from self-regulated learning.

Besides self-regulated learning variables, future orientation also influences learning achievement, some previous studies can explain. Research conducted by Sunarti (2013) the success of students in learning can be seen from themselves as individuals who play a direct role in learning activities. Future orientation as a form of self that plays a role in students' learning activities. Nurmi (2005) and Nurmi (1989) also explained that the orientation of the future is an image that the individual has about himself in the future context. Likewise Alfaiz's research (2019) that the potential for future orientation and forethought mindset determines the ability to visualize goals and behaviors to achieve these goals (Alfaiz et al, 2019).

Self-regulated learning and future orientation as internal factors that can review learning achievement. Parental support part of external factors also contribute to student learning achievement. Yuzarion research (2014) explains the attitudes of parents towards children have a positive and significant effect on student achievement, the better the attitude of parents towards children, the better the learning achievement of students. The attitude of parents towards children is an inseparable part of the form of parental support for children in learning, of course the right support will greatly affect their learning achievement.

Yuzarion's research findings (2015) also strengthen the relationship of self-regulated learning with learning achievement, along with the explanation that parents' attitudes towards children have a positive and significant effect on student learning achievement through self-regulated learning variables. It can be understood that either separately or independently parental support and self-regulated learning affect the learning achievement of students.

This is in line with the Word of Allah SWT in al-Quran surah al-Hasyr (59), verse (18); O you who believe, fear Allah and every individual should pay attention to what he has done for tomorrow (the hereafter); and fear Allah, indeed Allah is All-Knowing what you do. In this verse humans are given 
learning about the importance of future orientation. This means that the dimensions of life of anyone who has a future orientation will affect the results achieved, of course so also with students who have a future orientation will directly affect the achievements they obtain. Then it can be understood that learning achievement can be viewed from a future orientation.

Based on the results of the study above, it is still rarely investigated as to what the condition of the findings is if learning achievement is viewed from internal and external aspects in the context of the school environment for students. Then the researchers set this research formula as follows; to find out whether learning achievement can be viewed from self-regulated learning, future orientation and parental support to obtain empirical support, with the title of the study; "Learning Achievement Judging from Self Regulated Learning, Future Orientation, and Parental Support".

\section{Method}

The identification of research variables might be determined before the data collection method was determined. Research variable is an attribute, nature or value of people, objects or activities that have certain variations determined by researchers to be studied and drawn conclusions (Sugiyono, 2017). In this study, the researchers set four variables as psychological attributes, consisting of three independent variables and one dependent variable. The variables used in this study can be seen in the following table:

Table 1. Identification of research variable

\begin{tabular}{lll}
\hline Variable & Psychology atribute & Acronim \\
\hline (X1) & SelfRegulated Learning & SRL \\
(X2) & Future Orientation & FO \\
$(X 3)$ & Parents support & PS \\
$($ Y) & Learning achievement & LA \\
\hline
\end{tabular}

Explanations relating to each psychological attribute in this study could be followed by an explanation in the section of the research instrument. The subjects of this study were female active students in the XI class Yogyakarta Yuallimaat in even semester 2018/2019. Subjects totaling 103 students were drawn using the stratified total sampling technique. This research instrument used a scale that was assembled by a research teamas at the height of a writing supervisor, the scale referred to as follows: 1) Self-Regulated Learning Measurement Instruments. Measuring students' self-regulated learning used an instrument in the form of a scale developed by the research umbrella team elaborated on the characteristics of self-regulated learning from the Rochester Institute of Technology (Yuzarion, 2014). The instrument consisted of five indicators; (a) Independent in doing the tasks, (b) Able to make plans and strategies and control the time and learning process, (c) Utilize various learning resources available, (d) Able to maintain concentration and motivation to learn, and (5) Know how to process various information by utilizing various cognitive strategies; 3) Future Orientation Measurement Instruments. Measuring the future orientation of the students used an instrument in the form of a scale developed by the research umbrella team elaborated on the results of the modification of the scale of the future orientation of Seginer, (2009). The instrument consisted of three indicators; (a) motivation, (b) planning, and (c) evaluation; 4) Instruments for measuring parental support. Measuring parents' support students used instruments in the form of scales developed by the research umbrella team elaborated on aspects of social support from Sarafino (1994). The instrument consists of four indicators; (a) emotional, (b) instrumental, (c) informative, and (d) assessment; 5) Learning Achievement Instruments. Student learning achievements used instruments in the form of X subjects for midterm classes 2018/2019.

The data analysis techniques of this study are described as follows: 1) Descriptive Analysis. Descriptive analysis is intended to determine the distribution of respondents' responses to the scale of the research submitted. Sugiyono, 2017) explains descriptive analysis is a statistic used to analyze data by describing or describing data that has been collected as it is without intending to make conclusions that apply to the public or generalizations. Data obtained from the results of the study were calculated the mean and standard deviation to determine the tendency of the distribution of data obtained. As for interpreting the data obtained in the classification of subjects interpreted by category.; 2) Test Prerequisite 
Analysis. Prerequisite testing was done to determine whether hypothesis testing used parametric and nonparametric statistics. This study used a prerequisite test that was data normality test, this stage was carried out as one of the requirements before doing a regression test. The provisions seen from KolmogorovSmirnov significance value greater than 0.05 in the normality test results indicated the distribution of normal data (Hadi, 2012). Linearity test was the relationship could be tested with test for linearity. The relationship between the two variables will be said to be linear when the value of $p>0.05$ (Hadi, 2012). Multicollinearity test as a condition forregression analysis is justified when there is no relationship between independent variables. It can be known by the value of tolerance and VIF (Variance Inflation Factor). If the tolerance value $>0.1$ and VIF value $<5$, there will be no multicollinearity (Hadi, 2012 and Ghozali, 2013); 3) Hypothesis Test. Based on the research objectives that had been formulated, data analysis used in this study was multiple linear regression analysis aided by the SPSS 22.0 program for windows evaluation version. Multiple regression according to Sugiyono (2017) was used by researchers, if the researcher intends to predict how the condition (ups and downs) of the dependent variable (criterium), if two or more independent variables as predictor factors are manipulated (raised the value down).

\section{Results and Discussions}

Description of research data

Description of data with descriptive analysis was intended to determine the distribution of respondents' responses to the scale of the research submitted. Descriptive analysis gives meaning descriptively, the tendency that arises about the research variables according to empirical data without drawing a conclusion. The research sample consisted of 103 students, all subjects were female. Each description of the research variable data can be seen in the following table:

Table 2. The description of research data

\begin{tabular}{cccccc}
\hline Variabel & $\mathbf{N}$ & Min & Max & Mean & Std. Deviasion \\
\hline SRL & 103 & 70.00 & 114.00 & 93.31 & 7.93 \\
FO & 103 & 36.00 & 60.00 & 49.66 & 4.98 \\
PS & 103 & 82.00 & 127.00 & 105.10 & 11.29 \\
LA & 103 & 59.00 & 99.00 & 81.91 & 9.32 \\
\hline
\end{tabular}

Description:

SRL : Self regulated learning

FO : Future orientation

PS : parents support

LA : Learning Achievement

The table data above can be observed by the subject's response score on the self regulated learning (SRL) scale ranging from 70.00 to 114.00 , with an average subject response of 93.31 and a standard deviation of 7.93. Subject responses on the future orientation scale (OMD) ranged from 36.00 to 60.00 , with an average subject response of 49.66 and a standard deviation of 4.98 . Subject responses on the parent support scale (DOT) ranged from 82.00 to 127.00, with an average subject response of 105.10 and a standard deviation of 11.29. In the learning achievement data (PB), the subject's learning achievement scores ranged from 59.00 to 99.00 , with an average subject response of 49.66 and a standard deviation of 4.98 .

The diversity of responses obtained from subjects in each study variable, was used to determine the tendency of the subject's response to each research variable. The response trends of the subjects were grouped into three categories; high, medium and low. The standard used to describe the subjects in this study was an objective standard using empirical data of research findings with regard to the average value and standard deviation (standard deviation).

The data table categorization of research variables can be explained the majority of subjects' scores on the self-regulated learning variable are in the medium category of 68 (66.02\%) respondents, $23(22.33 \%)$ respondents in the high category, and $12(11.65 \%)$ respondents in low category. The score of subjects in the future orientation variable is in the medium category of 54 (52.43\%) respondents, 34 (33.01\%) 
respondents in the high category, and $15(14.56 \%)$ respondents in the low category. The highest score of subjects in the parent support variable was in the high category 79 respondents $(76.70 \%), 17(16.50 \%)$ respondents in the low category, and $7(6.80 \%)$ respondents were in the medium category.

Table 3. The catagories of research variable

\begin{tabular}{lllllllll}
\hline Kategori & SRL & \multicolumn{3}{c}{ FO } & \multicolumn{3}{c}{ PS } & \multicolumn{3}{c}{ LA } \\
\cline { 2 - 9 } & f & Percent & f & Percent & f & Percent & f & Percent \\
High & 23 & 22.33 & 34 & 33.01 & 29 & 28.16 & 79 & 76.70 \\
Medium & 68 & 66.02 & 54 & 52.43 & 50 & 48.54 & 7 & 6.80 \\
Low & 12 & 11.65 & 15 & 14.56 & 24 & 23.30 & 17 & 16.50 \\
\hline
\end{tabular}

Based on the description above, it can be concluded that the subject's response is in the medium category for the scale of self regulated learning, future orientation, and parental support, while students' learning achievement is in the high category.

\section{Test analysis prerequisites}

Analysis prerequisite test was a prerequisite before hypothesis testing, testing the correlation value so that the conclusions drawn do not deviate from the truth they should. The analytical prerequisite tests include normality tests, linearity tests, and multicollinearity tests, which can be explained in the following sections:

First normality test, this data normality test was done to find out whether the data of each research variable was normally distributed or not. The normality test was carried out using the KolmogorovSmirnov technique assisted by the SPSS application. Significance values greater than 0.05 in the normality test results indicated the distribution of normal data (Hadi, 2012). The results of the normality test calculation can be seen in the following table:

Table 4. The result of normality data

\begin{tabular}{|c|c|c|c|c|}
\hline \multirow{2}{*}{ Variabel } & \multicolumn{3}{|c|}{ Kolmogorov-Smirnov $^{\mathrm{a}}$} & \multirow{2}{*}{ Description } \\
\hline & Statistic & $\mathrm{df}$ & Sig. & \\
\hline SRL & .070 & 103 & .200 & Normal \\
\hline FO & .080 & 103 & .099 & Normal \\
\hline PS & .062 & 103 & .200 & Normal \\
\hline LA & .065 & 103 & .200 & Normal \\
\hline
\end{tabular}

The data table explains the results of normality testing data with the Kolmogorov-Smirnov technique obtained all the significance values of variables greater than 0.05 . Then it can be concluded that the data has a normal distribution.

Second linearity test, linearity test was performed to determine whether the relationship between independent variables and dependent linear or not, and to see the effect of independent variables on the dependent variable was directly or inversely proportional. Data was said to be linear if the Sig. deviation from linearity $>0.05$ (Hadi, 2012). The results of the linearity calculation can be seen in the following table:

The data above explains the results of testing data normality with ANOVA technique obtained all the significance values of variables greater than 0.05 . So it can be concluded that the research variables have a linear relationship.

Third multicollinearity test, multicollinearity test aims to test the linear relationship between independent variables. Multicollinearity can be known by reading the value of tolerance and variance inflation factor (VIF). If the tolerance value $>0.1$ and the VIF value $<5$, there will be no multicollinearity. Conversely, if the tolerance value $<0.1$ and the VIF value $>5$, there will be multicollinearity (Hadi, 2012 and Ghozali, 2013). Multicollinearity test results can be seen in the following table 5:

The data can be explained for multicollinearity test results by reading the tolerance value and variance inflation factor (VIF). Tolerance values for all independent variables $>0.1$ and VIF values $<5$ are 


\section{COUNS-EDU}

Vol.5, No.2, 2020

Available online: http://journal.konselor.or.id/index.php/counsedu

Yuzarion, Y. et al.

also all independent variables, so it can be concluded that there is no multicollinearity between the independent variables.

Table 5. The result of multicolinearity data

\begin{tabular}{llll}
\hline Variables & \multicolumn{2}{l}{ Collinearity Statistics } & Description \\
\cline { 2 - 3 } & Tolerance & VIF & \\
SRL & .756 & 1.323 & Unmulticolinearity \\
FO & .866 & 1.155 & Unmulticolinearity \\
PS & .751 & 1.331 & Unmulticolinearity \\
\hline
\end{tabular}

Based on the description of the results of the normality test, linearity test and the multicollinearity test above, the research data can be continued in the next test.

\section{Research hypothesis test}

The major hypothesis proposed in this study was that learning achievement could be viewed from self regulated learning, future orientation and parental support. Whereas the first minor hypotesis; Positive and significant learning achievement in terms of self-regulated learning, second; Positive and significant learning achievement in terms of future orientation, and thirdly positive and significant learning achievement in terms of parental support.

The data can be explained by the results of hypothesis testing showing learning achievement can be viewed from self-regulated learning, future orientation and parental support, as to the calculated $\mathrm{F}$ value of 43.155 , with a significance level of 0,000 . Significance level of $0,000<0.01$ this can explain that very significant learning achievement can be viewed from self regulated learning, future orientation and parental support, so that the major hypothesis proposed in this study learning achievement can be viewed from self regulated learning, future orientation and parental support can get empirical support. Look at the coefficient of determination in the table ( $\mathrm{R}$ Square) of 0.567 . This figure explains that self-regulated learning, future orientation and parental support can simultaneously review learning achievement with an effective contribution of $56.7 \%$.

The results of the first minor hypothesis test shows learning achievement can be viewed from selfregulated learning, the level of significance $p=0.001(p<0.05)$ and $t$ value of 3.494 is significant, so positive and significant learning achievement can be viewed from self-regulated learning get empirical support. Both learning achievement can be viewed from the future orientation, the level of significance $\mathrm{p}=$ 0.042 ( $p<0.05$ ) and the value of $t 2.059$ is significant, so positive and significant learning achievement can be viewed from the future orientation to get empirical support. All three learning achievements can also be viewed from parental support, the level of significance $p=0,000(p<0.01)$ and the $t$ value of 7.201 is significant, so positive and very significant learning achievements can be viewed from parental support for empirical support.

The effective contribution of the three variables can be explained; first self regulated learning could review learning achievement, calculated with the formula $\mathrm{SE}=\beta \times$ zero $\times 100 \%$ with a value of $\mathrm{SE}=$ $0.254 \times 0.502 \times 100 \%=12.74 \%$, thus self regulated learning can review learning achievement. The effective contribution of self regulated learning can review the learning achievement of $12.74 \%$. Both future orientations can review learning achievement, calculated by the formula SE $=0.151 \times 0.437 \times 100 \%$ $=6.59 \%$, thus the future orientation reviews learning achievement. The effective contribution of future orientation reviews $6.59 \%$ learning achievement. All three parental support can review learning achievement, also calculated with the formula SE $=0.539 \times 0.692 \times 100 \%=37.35 \%$, thus the support of parents ahead to review learning achievement. The effective contribution of parental support reviewed $37.35 \%$ learning achievement.

Students who get high scores from study results or exams, say they have high learning achievements for study results or tested subjects, and conversely students who get low scores from study or exam results, say they have low learning achievements for study results or subjects tested (Yuzarion, 2014). This is in line with Alsa, 2005 learning achievement is a quantitative result obtained by students from the learning activities they obtain in the form of numbers. 
Learning achievement both qualitative and quantitative abilities, when analyzed using social cognitive theory from Bandura (1986), learning achievement can be explained through internal and external factors of students. Internal factors of students, learning achievement can be viewed from or influenced by self-regulated learning and future orientation. External factors of student learning achievement can be reviewed from or influenced by parental support. These three variables, the variables of self-regulated learning, future orientation, and parental support are the main focus of this study. The major research hypothesis proposed in this study is that learning achievement can be viewed from self regulated learning, future orientation and parental support. Whereas the first minor hypotesis; Positive and significant learning achievement in terms of self-regulated learning, second; Positive and significant learning achievement in terms of future orientation, and thirdly positive and significant learning achievement in terms of parental support.

Hypothesis test results of learning achievement can be reviewed from self-regulated learning, future orientation and parental support. The research findings explain that very significant learning achievement can be viewed from self regulated learning, future orientation and parental support. In a simpler formula it can also be explained that learning achievement can be significantly influenced by self regulated learning, future orientation and parental support. As a conclusion of testing the research hypothesis, the major hypothesis in this study is acceptable, with a total effective contribution of the three variables of selfregulated learning, future orientation and parental support of 56.7 percent.

The results of the first minor hypothesis test also show learning achievement can be viewed from self-regulated learning. The results of the first minor hypothesis test of positive and significant learning achievement can be reviewed from self regulated learning. The effective contribution of self-regulated learning to learning achievement is 12.74 percent.

The results of the second minor hypothesis test of learning achievement can be viewed from future orientations. The results of the second minor hypothesis test of positive and significant learning achievement can be viewed from future orientations. The effective contribution of future orientation towards learning achievement is 6.59 percent.

The results of the third minor hypothesis test of learning achievement can also be viewed from parental support. The results of the third minor hypothesis test of positive and very significant learning achievement can be reviewed from parental support. Effective contribution of parental support for learning achievement 37.35 percent.

The results of this study strengthen Bandura's (cognitive) social cognitive theory, focusing on the one-way model. According to Bandura (1977b) the concept of two-way interaction in triadic reciprocality can be used the concept of one-way interaction with a focus on the most determining factor (the strongest influence) on the variables affected. In this study, the strongest influence was on the parental support variable. This means that learning achievement can be reviewed most strongly from the parent support variable. As well as reinforcing the research findings of Yuzarion (2014) that parents' attitudes towards children have a positive and significant effect on student achievement, the better the attitude of parents towards children, the better the learning achievement of students. The attitude of parents towards children is an inseparable part of the form of parental support for children adalam learning, of course the right support will greatly affect their learning achievement. The findings of these two studies empirically reinforce the findings of previous studies as described in the introduction to this study.

The findings of this study study achievement can be reviewed positively and significantly from self regulated learning, this strengthens the research findings of Yuzarion (2014) relating to self regulated learning, both as an independent variable and as an intermediate variable to learning achievement. Parents' attitudes towards children have a positive and significant effect on student achievement through the selfregulated learning variable. It can be understood that either separately or independently parental support and self-regulated learning affect the learning achievement of students. When internal factors such as future orientation are a potential for self-efficacy in visualizing learning experiences, they will help achieve learning behavior (Alfaiz, 2014; Alfaiz et al, 2017, 2019).

This finding is also corroborated by research by Nurafifah, Djamal and Hikmawati (2009). There is a positive and significant correlation between future orientation and self regulated learning as a predictor of learning achievement. Although this research does not specifically explain the relationship between future orientation and learning achievement. Students who have been independent in working on 
assignments, making plans and strategies as well as controlling the time and learning process, utilizing various learning resources available, maintaining concentration and motivation to learn, and managing various information by utilizing various cognitive strategies. Then they will have a higher learning presentation compared to other students. This can be seen from the average distribution of subjects' response scores on a self regulated learning (SRL) scale ranging from 70.00 to 114.00 , with an average subject response of 93.31 and a standard deviation of 7.93 .

Likewise with the parent support variable as the variable with the greatest contribution to learning achievement. Students who have the desire to believe in someone, as well as the attachment to someone, is caused by the belief that someone is able to give love, in this case parents. Parents' readiness in providing suggestions for learning in the form of learning equipment and various other facilities. Likewise with the provision of advice, explanations in the form of direction and provide information to overcome a problem and try to provide feedback provided by parents on the basis of support provided. Then the results of research conducted by Yandri and Juliawati (2018) also showed that adolescents who did not get the love of their parents tended to have problems in learning. All of these indicators positively contribute to reviewing learning achievement in the subjects of this study, this is evidenced from the findings of the third minor hypothesis of learning achievement can also be viewed from parental support. The results of the third minor hypothesis test of positive and very significant learning achievement can be reviewed from parental support. This result is also reinforced by the average distribution of subject response scores on the parental support scale ranging from 82.00 to 127.00 , with an average subject response of 105.10 and standard deviation of 11.29 .

Future orientation variables also contribute positively and significantly to learning achievement. Students who have a good future orientation, this is in line with proper motivation, planning, and selfevaluation. Motivation is an indicator of self which shows strong interest from individuals for a better future. Manat will be the director for setting educational goals in the future. Along with motivation and strong interest will affect learning achievement.

A clear future orientation on students functions in making self-planning. Planning functions as the process of forming future goals to be achieved. Both simple goals and more complex goals relate to the future. Along with the placement of the right goals this will affect learning achievement.

Future orientation also involves evaluation as a process that functions to evaluate the plans and goals set by individuals. Appropriate and correct evaluation in guarding the participant's future orientation certainly contributes to learning achievement. The research findings and findings above are supported by the following studies; Research conducted by Sunarti (2013) the success of students in learning can be seen from themselves as individuals who play a direct role in learning activities. Future orientation as a form of self that plays a role in students' learning activities. Nurmi (2005) also explains that the orientation of the future is an image that an individual has about himself in the future context.

Furthermore, the research findings of Jembarwati (2015) describe students who have a strong orientation or desire to succeed in the academic field will show good academic performance in completing academic tasks well as well. Students who have a good future orientation will be useful will make individuals pay close attention to future results with the acquisition of current achievements (Seginer, 2009).

Based on the discussion outlined above, the empirical findings of this study could be justified. First, a very significant learning achievement can be reviewed in terms of self-regulated learning, future orientation and parental support that has received empirical support. Second, parental support is the variable with the greatest contribution empirically reviewing learning achievement, because parents have a special emotional relationship with students and are also strengthened by the support of good learning infrastructure that has been given by parents. Third, self-regulated learning and future orientation, each also partially contributes to reviewing the achievements of empirical support.

\section{Conclusions}

Based on the results of the study, it can be concluded as follows: First, learning achievement can be viewed from self-regulated learning, future orientation, and parental support is very significant empirical support. The three variables contributed an effective contribution of 55.4 percent to learning achievement. 
Second, positive and significant learning achievements can be reviewed from self-regulated learning. Third, positive and significant learning achievements. It can be viewed from future orientations. Fourth, positive and very significant learning achievement can be viewed from the support of parents. Fifth, based on these findings, researchers suggest: First, parents need to maximize learning support for children, strengthen emotional support, instrumental, and informative. Second, teachers need to introduce self-regulated learning to students. Third, teachers and parents explore the future orientation of children or students well, so that they grow stronger for a more planned future. Fourth, researchers recommend the following research in elementary school, junior high school, senior high school and PT.

\section{References}

al-Quran. Ar-Rahman, Tafsir Qur'an Perkata. Dilengkapi terjemahan, asbabun nuzul, munasbah ayat, hadits seputar ayat, dan hikmah. Penulis Ahmad Hatta. (2011). Jakarta: Magfirah Pustaka.

Alfaiz. (2014). Pembelajaran Afektif Merupakan Salah Satu Strategi Dalam Pembentukkan Karakter Peserta Didik. Jurnal Pelangi, Vol. 7, No. 1, 94-105. http://ejournal.stkip-pgrisumbar.ac.id/index.php/pelangi/article/view/152. https://doi.org/10.22202/jp.2014.v7i1.152.

Alfaiz, D., \& Yandri, H. (2015). Self Concept and Self Efficacy As A Ground Points in A Social Activities (An Analysis of Psychology Perspective: A Social Cognitive Theory). Jurnal Pelangi, 7(2), 45-52. http://ejournal.stkip-pgri-sumbar.ac.id/index.php/pelangi/article/view/203.

DOI: https://doi.org/10.22202/jp.2015.v7i2.203.

Alfaiz. A, Rafiola. R.H, Hariko. R, \& Zulfikar. Z. (2017). Condition and Shaping of Student Personality in Educational Process Through Transpersonal Psychology Perspective. Proceedings of The 3rd International Conference on Education and Training (ICET 2017). https://www.atlantispress.com/proceedings/icet-17/25883491. https://doi.org/10.2991/icet-17.2017.1

Alfaiz. (2017). Sufism Approached in School Counseling Service: An Analysis of Perspective Spiritual Counseling. Schoulid: Indonesian Journal of School Counseling. 2(1): pp. 1-7. https://doi.org/10.23916/008621423-00-0. http://journal.konselor.or.id/index.php/schoulid/article/view/42.

Alfaiz, A. (2018). Guidance and Counseling Profession: a Philosophy and Professional Challenges In The Future. Couns-Edu: International Journal of Counseling and Education, 3(1): pp. 44-47. DOI: https://doi.org/10.23916/0020180313420. http://journal.konselor.or.id/index.php/counsedu/article/view/134

Alfaiz, Yandri. H, Kadafi. A, Mulyani, R.R, Nofrita, Juliawati. D. (2019). Pendekatan Tazkiyatun An-Nafs Untuk Membantu Mengurangi Emosi Negatif Klien. Counsellia : Jurnal Bimbingan dan Konseling, 9

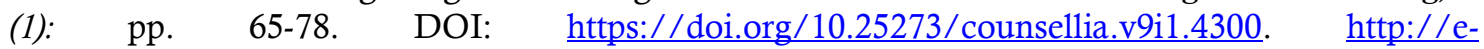
journal.unipma.ac.id/index.php/JBK/article/view/4300.

Alfaiz, A., Yandri, H., Yuzarion, Y., Lestari, L.P.S., \& Heriyani, E., (2019). Persepsi Agentik Individu untuk Mencapai Prestasi Pribadi dalam Aktivitas Karir: Riset Pendahuluan. Psychocentrum Review, Vol. $1, \quad$ No. 2, p.85-95. https://doi.org/10.30998/pcr.1276, https://journal.unindra.ac.id/index.php/pcr/article/view/76.

Alfaiz, Hidayah, N, Hambali, IM, \& Radjah, C. L. (2019). Human Agency as a Self-Cognition of Human Autonomous Learning: A Synthesized Practical of Agentic Approach. Journal of Social Studies Education Research. Vol. 10. No. 4. https://www.jsser.org/index.php/jsser/article/view/1370. https://doaj.org/article/0b2300a026e34cd0aa98a59161d05e7a.

Alsa, A. 2005. Program Belajar, Jenis Kelamin, Belajar Berdasar Regulasi Diri dan Prestasi Belajar Matematika Pada Pelajar SMA Negeri di Yogyakarta. Disertasi. Yogyakarta: PPs UGM.

Bandura, A. 1977b. Social Learning Theory. New Jersey: Prentise Hall, Inc.

Cekolin, C.H. 2010. The effect of self-regulated learning strategy instruction on strategy use and academic $\begin{array}{lllll}\text { achievement. } & 18 & \text { (1) } & 213-225, & \text { (Online), }\end{array}$ outhalabama.edu/coe/bset/idd/dis/cekolin.htm), diakses 28 September 2019.

Ghozali, I. 2013. Model Persamaan Struktural Konsep dan Aplikasi dengan Program Amos 21.0. Semarang: Badan Penerbit Universitas Diponegoro.

Hadi, S. (2012). Analisis butir untuk instrument. Yogyakarta: Andi

https://edukasi.kompas.com/read/2019/12/04/13002801/skor-pisa-terbaru-indonesia-ini-5-pr-besarpendidikan-pada-era-nadiem-makarim?page=all 
https://nces.ed.gov/timss/

Jembarwati, O. (2015). Pelatihan orientasi masa depan dan harapan keberhasilan studi pada siswa SMA. Humanitas, 12 (1), 45-51.

Juliawati, D. Ayumi, R.T. Yandri, H. \& Alfaiz, (2019). Efektivitas Relaksasi Teknik Meditasi untuk Membantu Siswa Mengatasi Stres sebelum Menghadapi Ujian Nasional. "Indonesian Journal of Learning Education and Counseling. Vol. 2. No. 1. 37-45. https://journal.ilininstitute.com/index.php/IJoLEC/article/view/151. https://doi.org/10.31960/ijolec.v2i1.151.

Nurafifah, F., Djamal, N.N., Hikmawati, F. (2009). Hubungan orientasi masa depan bidang pendidikan dengan keteraturan diri dalam belajar (self-regulated learning). Jurnal Ilmiah Psikologi Pendidikan dan Perkembangan, 1(1), 1-14.

Nurmi, J.E. (1989). Adolescents' orientation to the future: development of interest and plans, related attributions and affects, in the life-span context. Helsinki: Finnish Society of Sciences.

Nurmi, J.E. (2005). Thinking about and acting upon the future: development of future orientation across the life span. In A. Strathman \& J. Joireman (Eds.), Understanding behavior in the context of time: Theory, research, and application (p. 31-57). Lawrence Erlbaum Associates Publishers.

Sarafino, E.P. (1994). Health psychology biopsychosocial interactions. New York: John Kenedi.

Seginer, R. (2009). Future orientation: developmental and ecological perspectives. New York, NY: Springer.

Sugiyono. (2017). Metode penelitian kuantitatif kualitatif dan $R \& D$. Bandung: Alfabeta.

Sunarti. (2013). Pengaruh Intelegensi dan Motivasi Belajar terhadap Prestasi Belajar Siswa Kelas X SMA Negeri 6 Purworejo. 331-336.

Yuzarion. (2014). Model teoretis hubungan sikap orangtua terhadap anak, sikap guru terhadap siswa, dan selfregulated learning dengan prestasi belajar siswa (Studi faktor yang mempengaruhi prestasi belajar siswa SMAN di kota Malang). Disertasi, tidak terbit, Program Pacasarjana: UM Malang.

Yuzarion. (2015a). Studi teoretis faktor yang mempengaruhi prestasi belajar peserta didik. Ilmu Pendidikan Jurnal Kajian Teori dan Praktik Kependidikan, 42 (2), 182-191.

Yuzarion. (2015b). Studi tentang self-regukated learning (SRL) peserta didik di SMAN kota Malang. Jurnal Ilmiah Ekotrans, 15 (2), 109-119. 